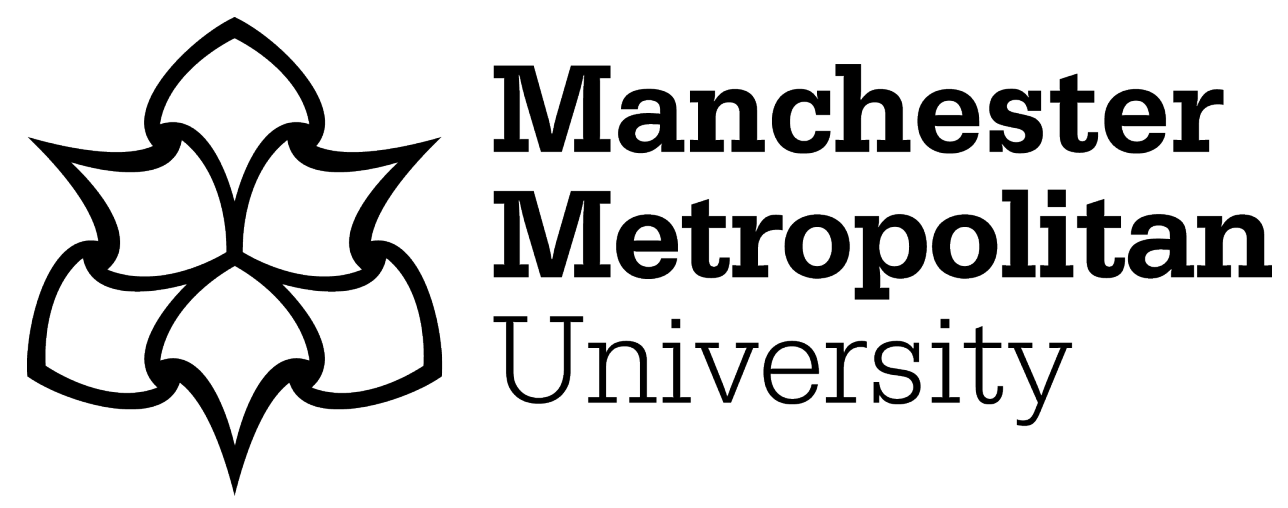

Nagy, GJ, Gutiérrez, O, Brugnoli, E, Verocai, JE, Gómez-Erache, M, Villamizar, A, Olivares, I, Azeiteiro, UM, Leal Filho, W and Amaro, N (2019) Climate vulnerability, impacts and adaptation in Central and South America coastal areas. Regional Studies in Marine Science, 29. p. 100683. ISSN 2352-4855

Downloaded from: https://e-space.mmu.ac.uk/623046/

Version: Accepted Version

Publisher: Elsevier

DOI: https://doi.org/10.1016/j.rsma.2019.100683

Please cite the published version 


\section{Climate vulnerability, impacts and adaptation in Central and South America coastal areas}

\section{Regional Studies in Marine Science}

Volume 29, May 2019, 100683

https://www.sciencedirect.com/science/article/pii/S2352485518304845

Gustavo J. Nagy a, Ofelia Gutiérrez a *, Ernesto Brugnoli a, José E. Verocai a, Mónica Gómez-Erache a, Alicia Villamizar ${ }^{b}$, Isabel Olivares ${ }^{c}$, Ulisses M. Azeiteiro ${ }^{d}$, Walter Leal Filho ${ }^{e}$, Nelson Amaro ${ }^{f}$.

a Instituto de Ecología y Ciencias Ambientales (IECA), Facultad de Ciencias, Universidad de la República, Igua 4225, CP 11400, Montevideo, Uruguay.

(NAGY, Gustavo J. - gnagy@fcien.edu.uy, GUTIÉRREZ, Ofelia - oguti@fcien.edu.uy, BRUGNOLI, Ernesto - ebo@fcien.edu.uy, VEROCAI, José E. - otolito@fcien.edu.uy, GÓMEZ-ERACHE, Mónica - mge@fcien.edu.uy)

b Departamento de Estudios Ambientales, Universidad Simón Bolívar, Sartenejas, Baruta, Edo. Miranda - Apartado 89000 Cable Unibolivar, Caracas, Venezuela.

(VILLAMIZAR, Alicia - alicia@usb.ve)

c Instituto de Ciencias Ambientales y Ecológicas, Facultad de Ciencias, Universidad de los Andes, Núcleo La Hechicera, Av. Alberto Carnevalli, Mérida (5101), Venezuela. (OLIVARES, Isabel - isabelolivaresicae@gmail.com)

d Department of Biology \& CESAM Centre for Environmental and Marine Studies, University of Aveiro, 3810-193 Aveiro, Portugal.

(AZEITEIRO, Ulisses M. - ulisses@uat.pt)

e Sustainable Development and Climate Change Management (FTZ-NK), Research and Transfer Centre (FTZ-NK), Faculty of Life Science, Hamburg University of Applied Sciences (HAW), Ulmenliet 20, D-21033 Hamburg, Germany.

(LEAL FILHO, Walter - walter.leal2@haw-hamburg.de)

f Instituto de Desarrollo Sostenible, Universidad Galileo, 7a. Avenida, calle Dr. Eduardo Suger Cofiño, Zona 10, Ciudad Guatemala, Guatemala.

(AMARO, Nelson - nelsonamaro@galileo.edu) 
* Corresponding author 


\section{HIGHLIGHTS}

- Central and South America coasts are vulnerable to climate-related hazards.

- Sea-level rise and vulnerability pose constraints to adaptation.

- Climate Change puts demands on coastal management.

There is a pressing need to foster adaptive capacity in coastal areas. 


\begin{abstract}
Low-Elevation Coastal Zones in Central and South America are exposed to climate-related hazards (sea-level rise, climate variability and storms) which threaten the assets (people, resources, ecosystems, infrastructure, and the services they provide), and are expected to increase due to climate change. A non-systematic review is presented focusing on vulnerability elements, impacts, constraints to adaptation, and their possible strategies. The analysis emphasises the Intergovernmental Panel on Climate Change Reasons for Concern (e.g., threatened systems, extreme events, aggregated impacts, and critical thresholds), particularly on sea-level rise, degradation of mangroves, and invasive alien species in Central and South America focusing on case studies from Uruguay and Venezuela. Despite recent advances in coastal adaptation planning in Central and South America, there is an adaptation deficit in the implementation of measures and strategies against climate-related hazards, such as sea-level rise. Adaptation constraints are linked with poverty, resource allocation, lack of political will, and lack of early warning systems for climate-related hazards. Non-structural adaptation measures such as community-based adaptation and ecosystem-based adaptation are not fully mainstreamed into national plans yet. Government-level initiatives (e.g. National Adaptation Programmes of Action) are being developed, but a few are already implemented. In addition to specific thematic measures, the implementation of non-structural approaches, National Adaptation Programmes of Action and early warning systems, based on the reasons for concern, should foster adaptive capacity in coastal areas.
\end{abstract}

Keywords: Coastal ecosystems; climate-related hazards; reasons for concern; mangroves; invasive alien species; adaptation strategies.

Introduction

Climate change and impacts in Central and South America coastal areas 1

\footnotetext{
${ }^{1}$ List of Abbreviations: AC, Adaptive Capacity; CBA, Community-based adaptation; CBD, Convention on Biological Diversity; COP, Conference of Parties; CSA, Central and South America; CRH, Climate-related hazards; CV, Notre Dame Gain Country Climate Vulnerability and Readiness Index; E, Exposure; EBA, Ecosystem-based Adaptation; ECLAC, Economic Commission for Latin America and the Caribbean; ENSO, "EI Niño"-Southern Oscillation; HDI, Human Development Index; IAS, Invasive Alien Species; IPCC Intergovernmental Panel on Climate Change; LECZ, Low Elevation Coastal Zones; NAPAs, National Adaptation Programmes of Action; ND-Gain, Notre Dame Global Adaptation Initiative; NOAA, National Oceanic and Atmospheric Administration; OHI, Ocean Health Index; PPSM, Public Policy System Model; RFC, Reasons for Concern; S, Sensitivity; SLR, Sea-level rise.
} 
The concentration of Greenhouse gases in the earth's atmosphere, mainly carbon dioxide (CO2), is directly linked to the average global temperature on Earth. According to the Intergovernmental Panel on Climate Change, human activities (e.g. burning fossil fuels, deforestation) have increased greenhouse gases to record levels which have not been seen in three million years causing climate change (IPCC, 2014a). Climate change is "A change in the state of the climate that can be identified (e.g., by using statistical tests) by changes in the mean and/or the variability of its properties and that persists for an extended period, typically decades or longer. Climate change may be due to natural internal processes or external forcings such as modulations of the solar cycles, volcanic eruptions and persistent anthropogenic changes in the composition of the atmosphere or land use" (IPCC, 2014a).

The increases in average global temperature $\left(+0.85^{\circ} \mathrm{C}\right.$ between 1880 and 2012) and frequent and high magnitude weather extremes are now posing a threat to the natural environment (IPCC, 2014b). It is very likely that global mean sea-level rose at a mean rate of $1.7 \mathrm{~mm} \mathrm{yr}-1$ between 1900 and 2010 and at a rate 3.2 mm yr-1from 1993 to 2010 (Wong et al., 2014).

Low Elevation Coastal Zones (LECZ) in Central and South America (CSA) are increasingly exposed to the effects of climate-related hazards (CRH) particularly sea-level rise (SLR), "El Niño"-Southern Oscillation (ENSO) and storms, which threaten its sustainable development and about $6 \%$ of the population (Villamizar et al., 2017). Significant impacts of climate change and SLR are expected for 2050-2080 (Magrin et al., 2007); furthermore, ENSO and extreme weather events are expected to become more frequent (Cai et al., 2014; IPCC, 2012).

Coastal ecosystems provide many services of their own, such as habitat for many species, thus supporting fishing and tourism and other economic activities (Muñoz Sevilla and Le Bail, 2017). Together with coral reefs, mangroves are ecosystems of strategic importance in Latin America (Silva et al., 2014) due to their importance to marine organisms, biology and ecology and associated fishing communities. They also tend to protect populations and infrastructure from storms and hurricanes, prevent beach erosion and control floods (Muñoz Sevilla and Le Bail, 2017).

There is a relationship between climate change and the changes observed in the environmental processes of marine-coastal ecosystems (Ummenhofer and Meehl, 2017) with consequences on the maintenance of biodiversity and the provision of services in CSA (Calil et al., 2017). Many marine species have shifted their geographic ranges, seasonal activities, migration patterns, abundances, and species interactions in response to climate change (IPCC, 2014c), and therefore climate change is a central element of the Aichi set of targets. The Aichi targets are part of the Strategic Plan for Biodiversity 2011-2020, adopted by the Conference of Parties to the Convention on Biological Diversity (CBD). The mission of the Strategic Plan is "stop the loss of biodiversity to ensure that by 2020 ecosystems are resilient and continue to provide essential services, thus ensuring the variety of life on the planet and contributing to human wellbeing and the eradication of poverty" (CBD, 2016).

Having the data on relative sea-level trends is crucial for coastal zone management, biodiversity conservation and ecosystem services (Silva et al., 2014), but adequate planning and conservation to reduce the environmental, socio-environmental and economic impacts is not yet fully achieved (Scherer et al., 2014). 
"In the absence of significant adaptation measures, coastal ecosystems will continue to be impacted by a changing climate" (Wong et al., 2014), particularly in the LECZ (Neumann et al., 2015), and the best approach to foster coastal resilience is to address the United Nations Sustainable Development Goals (United Nations, 2015), focusing on climate action and adapt to climate change (Leal Filho et al., 2018).

Climate resilience is "The ability of a system and its parts to anticipate, absorb, accommodate or recover from the effects of a hazardous event in a timely and efficient manner, including through ensuring the preservation, restoration or improvement of its essential basic structures and functions" (IPCC, 2012). In this context, our systemic understanding of the world needs improvement if we are to understand the consequences of the changes that mark the Anthropocene (Garnett, 2018). In this regard, Nagy et al. (2015) stated: "coastal adaptation efforts need to build on, and support, existing frameworks to strengthen coastal zone management".

This article deals with a review and commentary of selected topics of vulnerability, impacts and adaptation in coastal areas of CSA and presents a few case studies in Uruguay and Venezuela.

\section{Methodological Approach and Goals}

The working hypothesis is that all coastal areas in Central and South America show some degree of vulnerability. These territories are exposed and are directly or indirectly impacted by climate-related hazards (CRH) regardless of their socioeconomic and adaptation status; therefore, climate adaptation should be a priority. Climate adaptation is "The process of adjusting to new climate conditions to reduce risks to valued assets" (U.S. Climate Resilience Toolkit, 2018). Adaptation deficit is "The gap between the current state of a system and a state that minimises adverse impacts from existing climate conditions and variability" (IPCC, 2014a). The research problem is: How can CSA countries reduce their adaptation deficit to climaterelated hazards in coastal areas? This article seeks to give some responses to this question focusing on case studies.

The methodological approach is a non-systematic review of the current state of knowledge and priorities for future research of relevant $\mathrm{CRH}$ and non-climate stressors, vulnerability, and some impacts (mainly coastal tropical ecosystems, invasive alien species), and adaptation approaches. We have made an update of some of these issues based upon i) narrative, conceptual and thematic recent literature review, ii) unpublished data, iii) Relevant literature and iv) some new results from ongoing research. We focus on Central and South America and present case studies from Uruguay and Venezuela. The selection of examples is based on the concept of "Reasons for Concern" (RFC) which aims to facilitate judgements about what level of climate change may be dangerous by aggregating impacts, risks and vulnerabilities (IPCC, 2014a; O'Neill et al., 2017). The collected case studies show some of the complexities and importance of the impacts of CRH (SLR, ENSO) and non-climate stressors (globalisation, transportation, mismanagement), and adaptation measures and strategies. There is no claim of a detailed analysis of all issues and local problems. 
The following sections are as follows: Section 2 briefly summarises the climate threats and impacts on CSA coastal areas, focused on SLR and storms. Section 3 focuses on vulnerability and impacts. Section 4 includes the current state of adaptation, case studies, and examples of adaptation strategies. Finally, Section 5 discusses some perspectives on future research and concluding remarks.

Climate threats and impacts on coastal areas of Latin America

The United Nations and the IPCC reported examples of the intensification of CRH in the coastal areas of CSA over the last few decades. For instance, 39 hurricanes occurred in the Caribbean basin from 2000 to 2009, compared with only 15 and 9 in the 1980s and 1990s respectively (UNEP-ECLAC, 2010). The fifth IPCC report (AR-5) on adaptation in CSA showed that SLR increased from $2 \mathrm{~mm} / \mathrm{yr}$ in 1950 to $7 \mathrm{~mm} / \mathrm{yr}$ in 2008 threatening corals, fish stocks and mangroves (Magrin et al., 2014). ENSO-related variability has been associated with ecological changes in the coastal environment in CSA (Brugnoli et al., 2018; IPCC, 2014d; Wong et al., 2014), while extreme weather events have affected people, including fatalities, displacement and economic losses (Nagy et al., 2018).

The United Nations Global Urban Observatory developed a risk-map of coastal cities at risk due to flooding based on the $17 \mathrm{~cm}$ increase observed in the 20th century and the conservative global mean SLR projections ( 22 to $34 \mathrm{~cm}$ ) over the period 1990-2080 (UN-HABITAB, 2008). Some of the big cities at risk in CSA are Barranquilla (Colombia), Buenos Aires (Argentina), Caracas (Venezuela), Guayaquil (Ecuador), Fortaleza, Porto Alegre, Recife, and Rio de Janeiro (Brasil), Montevideo (Uruguay), and Panama City (Panama) (UN-HABITAB, 2008). Under IPCC scenarios for 2090-99 relative to 1980-99 ranging from 0.20 to $0.59 \mathrm{~cm}$ (IPCC, 2007), the risk would be higher.

Most of the coasts, where these cities are exposed to threats are at risk as defined by the Comparative Coastal Risk Index (Calil et al., 2017) which assesses the hazards, exposure and vulnerability due to storm surges and waves (the Rio de la Plata estuary region), and ENSO events (e.g. the Pacific coast of Ecuador and Peru). According to the Notre Dame Global Adaptation Initiative, Exposure is "Nature and degree to which a system is exposed to significant climate change, independent of socioeconomic context" (ND-Gain, 2016). Some of the main observed and projected coastal impacts in CSA relevant for this article are as follows (Villamizar et al., 2017):

Overfishing, habitat pollution, habitat destruction, and the invasion of foreign species that negatively impact biodiversity and the delivery of ecosystem services (Guarderas et al., 2008).

The most significant flooding levels (hurricanes not considered) are found in the Rio de La Plata area (Argentina and Uruguay) (Izaguirre et al., 2013).

Despite IPCC reports mentioned above that highlight SLR globally (Wong et al., 2014) and in CSA (Magrin et al., 2014), there is scarce data for CSA. We have briefly summarised most available data from international databases and the literature (Table 1). 
Vulnerability

Vulnerability

Climate vulnerability is defined as "The propensity or predisposition of assets to be adversely affected by hazards. Vulnerability encompasses exposure, sensitivity, potential impacts, and adaptive capacity" (U.S. Climate Resilience Toolkit, 2018).

According to Villamizar et al. (2017), CSA countries may be classified with respect to their country-level and coastal climate vulnerability status (exposure + sensitivity - adaptative capacity) in three main categories: i) moderate: Argentina, Brazil, Chile and Uruguay, ii) high: Colombia, Costa Rica, Ecuador, Guyana, Panamá, Peru, Suriname and Venezuela, and iii) very high (Belize, El Salvador; Guatemala, Honduras and Nicaragua). This classification depends on a different degree of availability of climate adaptation plans and strategies, institutional capacity-building, social capital, and, the level of reliance on international assistance, particularly in cases where extreme events affect them (Leal Filho and Mannke, 2014; Villamizar et al., 2017). The CSA countries with the highest number of people living in very high coastal risk areas are Ecuador, El Salvador, Honduras, Nicaragua, Guatemala and Peru (Calil et al., 2017).

Table 2 summarises some updated indicators of vulnerability and adaptation at the countryand coastal-level. The lack of available disaggregated country-level data into the coastal-level in CSA countries hampers regional analysis (Villamizar et al., 2017). The indicators and the index used are i) \% of the population living at LECZ; ii) Human Development Index-HDI (UNDP, 2016), iii) Notre Dame Gain Country Vulnerability Index (CV) (ND-Gain, 2016), and iv) the Ocean Health Index-OHI (OHI, 2017). CV encompasses (Exposure + Sensitivity - Adaptive capacity) and summarises a country's vulnerability to climate change and weather-related hazards impacts (ND-Gain, 2016).

Sensitivity is "The extent to which a country is dependent upon a sector negatively affected by climate hazard, or the proportion of the population particularly susceptible to a climate change hazard" (ND-Gain, 2016). Herein the sector is the coastal area. Adaptive Capacity is "The ability of systems, institutions, humans and other organisms to adjust to potential damage, to take advantage of opportunities, or to respond to consequences" (IPCC, 2014a).

Table 1. Sea-level rise in countries of Central and South America. Sources: The authors based on the Permanent Service for Mean Sea Level (PSMSL) (https://www.psmsl.org/)* of the U.S. National Oceanic and Atmospheric Administration (NOAA), and literature references.

\begin{tabular}{lllll}
\hline Country & Sites & $\begin{array}{l}\text { Sea-level rise } \\
(\mathrm{mm} / \mathrm{year})\end{array}$ & Record & References \\
\hline \multirow{2}{*}{ Argentina } & Buenos Aires & 1.57 & $1905-1987$ & Raicich (2008) \\
\cline { 2 - 5 } & Buenos Aires & 1.70 & $1901-2000$ & Magrin et al. (2007) \\
\hline Brazil & Cananeia & 2.58 & $1978-2000$ & PSMSL (2017) \\
\end{tabular}




\begin{tabular}{|c|c|c|c|c|}
\hline & Fortaleza & 2.20 & $1965-2013$ & \\
\hline \multirow{2}{*}{ Chile } & Calderas & 3.01 & 1980-1998 & \multirow{2}{*}{$\begin{array}{l}\text { NOAA (2018); PSMSL } \\
(2017)\end{array}$} \\
\hline & Punta Arenas & 5.91 & 1941-1969 & \\
\hline \multirow{2}{*}{ Colombia } & Cartagena & 5.30 & 1948-1992 & \multirow{2}{*}{ PSMSL (2017) } \\
\hline & Buenaventura & 0.96 & 1941-1969 & \\
\hline Costa Rica & Quepos & 0.63 & $2009-2017$ & NOAA (2018); \\
\hline \multirow{2}{*}{ Ecuador } & Baltra-B & 1.16 & $1986-2014$ & \multirow{2}{*}{$\begin{array}{l}\text { NOAA (2018); } \\
\text { PSMSL (2017) }\end{array}$} \\
\hline & La Libertad II & -1.28 & $1949-2003$ & \\
\hline El Salvador & Acajutla & 2.89 & $1962-2001$ & NOAA (2018) \\
\hline Honduras & Puerto Cortés & 7.87 & $1947-1968$ & PSMSL (2017) \\
\hline \multirow{2}{*}{ Panama } & Cristobal & 1.41 & $1909-1980$ & \multirow{2}{*}{$\begin{array}{l}\text { NOAA (2018); } \\
\text { PSMSL (2017) }\end{array}$} \\
\hline & Balboa & 1.45 & $1908-2016$ & \\
\hline \multirow{2}{*}{ Perú } & Mataroni & -0.84 & $1942-1969$ & \multirow{2}{*}{ PSMSL (2017) } \\
\hline & Talara & 0.97 & 1943-1969 & \\
\hline \multirow{2}{*}{ Uruguay } & Montevideo & 1.37 & $1938-2015$ & PSMSL (2017) \\
\hline & Montevideo & 1.46 & $1902-2016$ & Verocai et al. (2016) \\
\hline
\end{tabular}

* These data should be used with some care as anomalous trends have many causes: land movements (e.g. glacial isostatic adjustment); unexplained instrumental datum shifts; changes in atmospheric pressure; short records (PSMSL, 2017). 
Table 2. Country-level human development (HDI: 0.35-0.95) (UNDP, 2016), climate vulnerability (CV: 0.27-0.68) elements: exposure (0.25-0.72), sensitivity (0.12-0.62), and adaptive capacity (0.18-0.88) indicators (ND-Gain, 2016), and Ocean Health Index (OHI: 42-92; Global Ocean average: 70) (OHI, 2017) in Central and South America. The world range of values is indicated in parenthesis. The three highest and lowest-placed countries are underlined and written in bold respectively.

\begin{tabular}{|c|c|c|c|c|c|c|c|}
\hline \multirow{3}{*}{ Countries } & \multirow{3}{*}{$\begin{array}{l}\text { \% Pop. Living } \\
\text { at LECZ }\end{array}$} & \multirow{3}{*}{ HDI } & \multicolumn{4}{|c|}{ ND Climate Vulnerability (E+S-AC) } & \multirow{3}{*}{$\begin{array}{l}\mathrm{OHI} \\
2017\end{array}$} \\
\hline & & & \multicolumn{4}{|c|}{ (0: minimum; -1 : maximum) } & \\
\hline & & & $E$ & $S$ & $A C(-)$ & $\mathrm{CV}$ & \\
\hline Argentina & 10 & 0.83 & 0.47 & 0.25 & 0.38 & 0.37 & 66 \\
\hline Belize & 39 & 0.71 & 0.47 & 0.49 & 0.51 & 0.49 & 67 \\
\hline Brazil & 7 & 0.75 & 0.50 & 0.26 & 0.38 & 0.38 & 66 \\
\hline Chile & 2 & 0.85 & 0.38 & 0.27 & 0.38 & 0.34 & 71 \\
\hline Colombia & 3 & 0.73 & 0.50 & 0.20 & 0.47 & 0.39 & 60 \\
\hline Costa Rica & 2.5 & 0.78 & 0.45 & 0.32 & 0.42 & 0.40 & 63 \\
\hline Ecuador & 14 & 0.74 & 0.53 & 0.33 & 0.48 & 0.40 & 70 \\
\hline El Salvador & 3.5 & 0.68 & 0.47 & 0.38 & 0.50 & 0.45 & 53 \\
\hline Guatemala & 1.5 & 0.64 & 0.48 & 0.41 & 0.49 & 0.46 & 62 \\
\hline Guyana & 56 & 0.64 & 0.40 & 0.47 & 0.54 & 0.48 & 63 \\
\hline Honduras & 4 & 0.63 & 0.44 & 0.40 & 0.54 & 0.46 & 68 \\
\hline Nicaragua & 2.5 & 0.65 & 0.49 & 0.38 & 0.48 & 0.45 & 48 \\
\hline Panama & 8 & 0.79 & 0.45 & 0.36 & 0.42 & 0.41 & 64 \\
\hline Peru & 2 & 0.74 & 0.46 & 0.29 & 0.53 & 0.43 & 61 \\
\hline Suriname & 68 & 0.73 & 0.42 & 0.32 & 0.42 & 0.40 & 75 \\
\hline Uruguay & 13 & 0.80 & 0.45 & 0.32 & 0.37 & 0.38 & 61 \\
\hline Venezuela & 6 & 0.77 & 0.42 & 0.25 & 0.37 & 0.35 & 59 \\
\hline Median & 7 & 0.74 & 0.44 & 0.38 & 0.47 & 0.40 & 64 \\
\hline
\end{tabular}

Note LECZ, Low Elevation Coastal Zones; HDI, Human Development Index, which organises indicators into three main dimensions of human well-being: health, education, and income (UNDP, 2016); E, Exposure; S, Sensitivity; AC, Adaptive Capacity: CV, Notre Dame Gain Country 
Vulnerability Index; OHI, Ocean Health Index. 
Table 2 shows a qualitative relationship between HDI and CV; the countries of Argentina, Brazil, Chile and Uruguay show the lowest country-level CV and, mainly, the greater adaptive capacity, while Belize, El Salvador, Guatemala, Guyana, Honduras, Nicaragua, and Peru show the greater CV and lowest adaptive capacity. People living at LECZ is a coastal exposure proxy, not strongly related to country-level exposure, except in the case of Belize, and less clearly in Ecuador and Uruguay. The $\mathrm{OHI}$ placement is not related to $\mathrm{CV}$ indicators and shows a few countries with a low ecological status concerning global and regional average (e.g. El Salvador, Nicaragua, and Venezuela).?

Impacts

This section presents three case studies: i) sea-level rise, ii) ecological impact faced by mangrove ecosystems, and iii) colonisation by Invasive Alien Species (IAS), which were selected to highlight the complexity and importance of SLR and ENSO-related variability (case 1), as well as aggregate causes (case studies 2 and 3 ) in the countries of Uruguay and Venezuela. These examples are related to the following IPCC Reasons for Concern:

i): Risks to unique and threatened systems (RFC1).

ii) Risks associated with extreme weather events (RFC2).

iii) Risks related to global aggregate impacts (RFC4), and

iv) RFC5: Risks related to large-scale singular events (sometimes called tipping points or critical thresholds) in response to smooth variations in driving forces (accompanied by natural variability) where risk is the potential for negative consequences, whereas impacts are the manifestation of that potential (O'Neill et al., 2017).

Sea-level rise was used as a metric of climate-related hazards in addition to global warming where the transition from undetectable to moderate risk started before the recent period (1986-2005), increasing the risk of flooding. The risk is judged to reach the Moderate level at about $10 \mathrm{~cm}$ above the 1986-2005 level (O'Neill et al., 2017).

Sea-level rise. Case study: Montevideo harbour, Uruguay

A sea-level time series of Montevideo harbour (Rio de la Plata estuary) is selected because it provides a long-term (1902-2016) case study related to RFCs 1 and 2 and, is part of the Global Sea Level Observing System programme since the 1990s, (Station $=300$ (Figure 1).

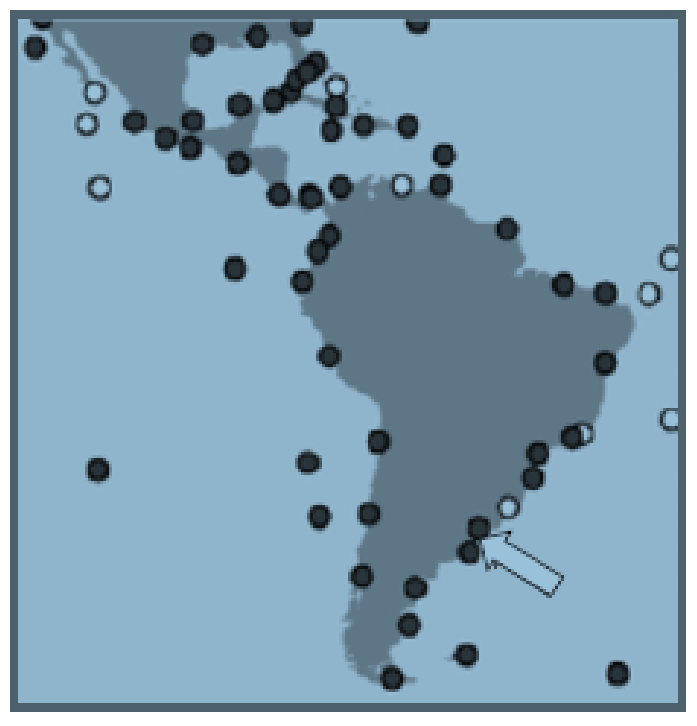

Active (248) Inactive (42)

Global Sea Level Observing System (GLOSS) is establishing a welldesigned, high-quality sea level observing network to support broad research and operational user base (August 2018). Dark points indicate operational stations. The arrow shows Montevideo station $\left(\mathrm{N}^{\circ} 300\right)$. 
Figure 1. Latin America sea-level Global Sea Level Observing System stations. Source: PSMSL (2017).

According to Verocai et al. (2016), average sea-levels at Montevideo's coast have increased $\geq 11 \mathrm{~cm}$ from 1902 to 2016 , with a significant positive trend with time ( $r 2=0.225 ; p<0.0001$; rate $0.9 \mathrm{~mm} /$ year). Over the period 1961-2014 both mean sea-level and the acceleration rate fluctuated, with an acceleration from 1971 to 1998 (Nagy et al., 2007) and a stabilisation from 1999 to 2010 (Verocai et al., 2015). In addition to the observed increase in mean sea-level, over the last 20 years, a raised interannual variability of $30 \mathrm{~cm}$ was observed, partly attributable to the increased frequency and intensity of ENSO events (Gutiérrez et al., 2016). In particular, acceleration was observed over the most recent few years (2013-2016). REFERENCE??

The Montevideo SLR time-series (Figure 2) reflects both global trends and ENSO-related regional influence at the same time (Nagy et al., 2014a); the latter includes local river discharges and wind effects (Gutiérrez et al., 2016; Verocai et al., 2016, 2015). The acceleration observed since 2014 follows trends in global acceleration, with a peak triggered by "El Niño" 2015-16. Despite the fact that the observed SLR since the 1986-2005 level is below the moderate risk, the local trend observed since 2016 suggests that this level could become an impact soon, which is in line with the global climate acceleration trend from 2015 to 2018 "Global mean sea level for 2018 was around $3.7 \mathrm{~mm}$ higher than in 2017 and the highest on record" (WMO, 2019).

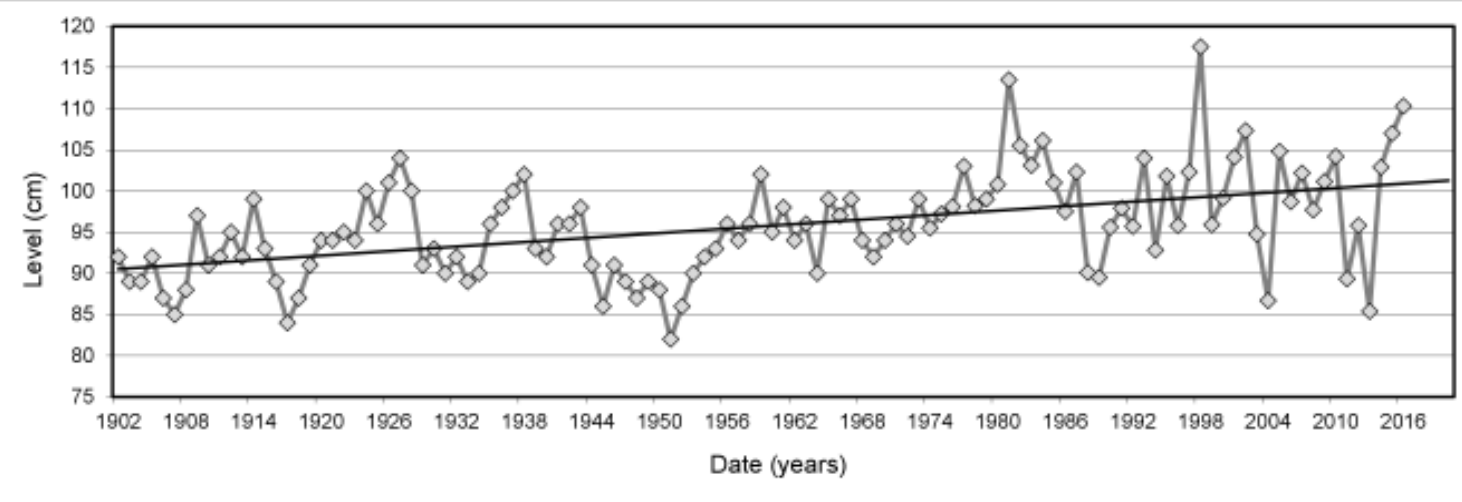

Figure 2. Yearly mean sea-level at Montevideo harbour, Uruguay.

Source: The authors updated these figures from previous time-series 1902-2013. 
Mangrove ecosystems in the Latin America and Caribbean region cover approximately $28 \%$ of the total area of LECZ occupied by these ecosystems worldwide (Spalding et al., 2011) and are related to all RFCs, particularly RFC 1 (Risks to unique and threatened systems). Mangroves predominantly develop along the tropical and intertropical coasts of the Americas (YáñezArancibia and Lara-Domínguez, 1999) providing valuable ecosystem services such as: a) coastal protection, b) carbon sequestration, and c) nurseries for the reproduction of fish, among others (Godoy and Lacerda, 2015). Even though global carbon storage and sequestration have been recognised as a valuable climatic mangrove ecosystem service (Breithaupt et al., 2012); mangrove protection initiatives are poorly implemented at present (Adame et al., 2018).

"The inland incursion of saltwater due to SLR creates estuarine substrates capable of being inhabited by mangrove species, but the diversity and spatiotemporal dynamics of mangrove substrates makes it difficult to record how much carbon can be sequestered or released in these new substrates" (based upon Adame et al., 2018; Breithaupt et al., 2012; Godoy and Lacerda, 2015). Non-climate stressors (e.g. land-use changes) increase the vulnerability of mangrove areas due to their increased exposition to the direct effects of SLR (Coastal Protection for Climate Change Adaptation in the Small Island States in the Caribbean) (CCCCC, 2017). On the other hand, erosion and coastal accretion (Breithaupt et al., 2012), have decreased biodiversity (Devaney et al., 2017), and have led to the alteration of ecosystem services, leading to disruptions in the livelihoods and causing inequalities among communities (Vieira, 2016).

Climate and non-climate stressors compromise the ecosystem services provided by coastal ecosystems, their associated human populations, and the maintenance of the systemic equilibrium of the coastal zone. According to the Economic Commission for Latin America and the Caribbean, the complex set of impacts that derive from the interaction of stressors and the limited existence of specific policies to address them leads to negative feedback mechanisms that may affect mangrove resilience (ECLAC, 2018).

Invasive Alien Species (IAS)

The Convention on Biological Diversity defines Invasive Alien Species (IAS) as "plants, animals, pathogens and other organisms that are non-native to an ecosystem, and which may cause economic or environmental harm or adversely affect human health" (CBD, 2018). IAS cause changes in the composition and function of ecosystems and their services, affecting human wellbeing. They have become a significant component of global change and pose a serious threat to local and global biodiversity (Vilà and Ibáñez, 2011). The IAS is related to RFCs 2 and 5 (large-scale singular events). 
For a species to become an IAS, it must successfully transit three distinct stages or the invasion process (Blackburn et al., 2014). Climate change can disrupt different aspects of these invasion stages, as described in Figure 3.

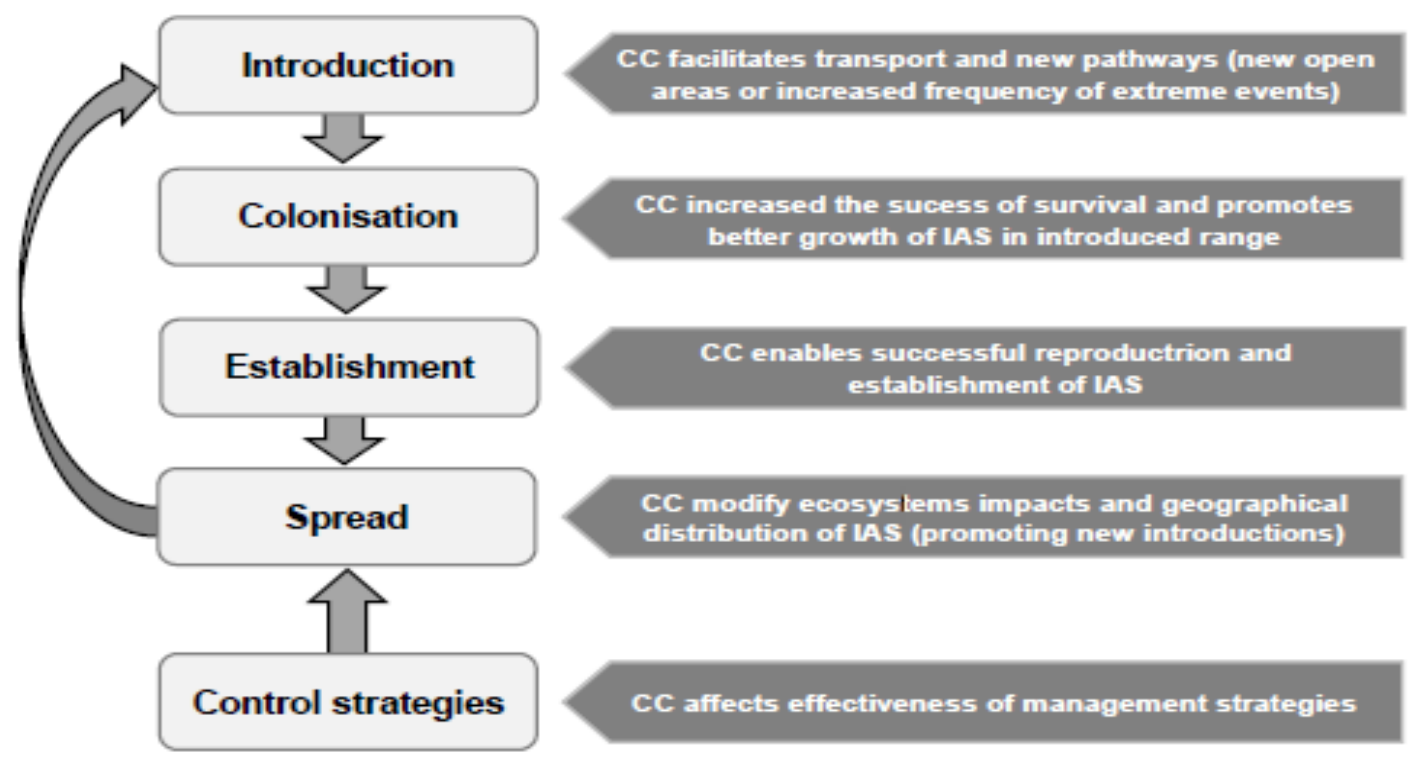

Figure 3. Stages of IAS invasion process disrupted by climate change (modified from Hellmann et al., 2008; Walther et al., 2009).

An example of a highly distributed IAS in coastal ecosystems is the lionfish (Pterois volitans and P. miles), which is spread along the US East Coast, the Caribbean islands throughout, Colombia and Venezuela (Betancur-R. et al., 2011; Schofield, 2009). The lionfish affects food and cultural ecosystem services due to predation of the indigenous fish fauna of mega-diverse coastal marine ecosystems. The species was recently reported in the south-eastern Atlantic coast of Brazil, due to its euryhaline and eurythermal features. Source?

Fostering adaptation

The current state of adaptation in Central and South America

Central and South America countries are vulnerable to climate change, which is also due to their restricted adaptation capacity, and are likely to remain so unless fundamental changes in decision-making processes are implemented (Leal Filho and Mannke, 2014). Several authors have stated an increase in climate adaptation efforts over the last decade (e.g. EuropeAid, 2009; Magrin et al., 2014; Nagy et al., 2015), especially those focused on coastal management strategies, better protection of ecosystems, and early warning systems. However, such efforts are constrained by a lack of resources, capacity, and adequate regulatory frameworks, a limited awareness regarding climate change particularly at the political level, ecosystem degradation, missing data and information, low-income levels, complex disasters and conflicts (EuropeAid, 2009; Leal Filho and Mannke, 2014; Villamizar et al., 2017). 
The classic adaptation strategies (e.g. top-down plans, Integrated Coastal Zone Management, socioeconomic development, capacity building, institutional strengthening, response against hazards, and hard engineering solutions) are not enough to reduce the impacts of climaterelated hazards, nor are they flexible enough to cope with an uncertain and changing future (Leal Filho et al., 2018). More recent strategies such as Ecosystem-based Adaptation (EBA) and National Adaptation Programmes of Action (NAPAs) should be more adaptive to face uncertainty (Leal Filho et al., 2018).

Ecosystem-based Adaptation (EBA)

Ecosystem-based Adaptation (EBA) promotes more resilient coastal areas (Braga et al., 2018) by means of the protection of the related ecosystems. EBA is "the use of biodiversity and Ecosystem Services to help people adapt to the adverse effects of climate change as part of an overall adaptation strategy" (CBD, 2016).

A successful EBA case study was developed in Kiyú (Uruguayan coast of the Rio de la Plata estuary) where stakeholders implemented measures to reduce the erosion of sandy beaches and dunes due to $\mathrm{CRH}$ and poor management practices (Carro et al., 2018). The adaptation process was developed through vulnerability assessments (Nagy et al., 2014b) including managers, stakeholders, and experts. This exercise provided social legitimacy, knowledge exchange between stakeholders, and incorporation of EBA approaches by the subnational coastal governments (Carro et al., 2018; Nagy and Gutiérrez, 2018). The recovery processes of coastal ecosystems were implemented through soft measures (green infrastructure) such as the regeneration of dunes, reforestation with native species, and the reduction of use pressures.

Multi-participatory mainstreaming approaches: The case of Mangroves

Most traditional policy actions implemented in the tropical CSA Low-elevation Coastal Zone (LECZ), e.g. the Integrated Coastal Zone Management approach, are mainly oriented towards the evaluation of risks, vulnerability and the reduction of impacts in mangrove areas (Villamizar, 2011; Villamizar et al., 2017). Building climate-resilient mangrove ecosystems will require a transformational change by all government scales to overcome the limitations of adaptation linked to the allocation of resources to priorities other than climate change (e.g. poverty). The everyday adaptation experiences developed by the academy in CSA usually follow the community-based adaptation (CBA), and the EBA approaches (Villamizar et al., 2017). Approximately $85 \%$ of the Venezuelan coastline, including nineteen mangrove protected areas, is a Low Elevation Coast (LECZ) at risk of impacts from SLR under all IPCC scenarios, totalling $5,600 \mathrm{~km} 2$ of wetlands, mainly mangroves (ACFIMAN-SACC, 2018).

An alternative comprehensive approach to mainstreaming local adaptation plans is the Public Policy System Model (PPSM) (Villamizar, 2011) developed in the Hueque-Sauca Wildlife Reserve (The reserve), Falcon State-Venezuela, on low elevation coast (Villamizar, 2011). The objective of the PPSM is to generate adaptation measures to protect local communities, and mangrove ecosystems against the effects of SLR within the framework of the Integrated Coastal Zone Management Plan contemplated in the Coastal Zones Law. 
The reserve is a poor rural Protected Area (37,100 ha and a low-lying coast of 1,600 m in length) for a Cayman threatened species (Crocodylus acutus) and for the 5,000 ha of mangrove, $10 \%$ of which has been lost due to the combined effect of extreme droughts and poor management. The impact of socio-productive activities and natural ecosystems by the permanent inundation caused by the SLR requires adaptation actions incorporated in public policies.

The reserve has three adaptation goals: 1 ) identification of factors and implications associated with SLR; 2) identification of intervening elements; 3 ) operationalisation of the PPSM in adaptation to the impacts of SLR. The adaptation measures combine CBA, and EbA approaches: 1 ) increasing awareness at all levels; 2 ) promoting research-oriented decisionmaking; 3 ) empowering the coastal communities to perceive and respond to the effects of climate change; 4) building adaptation capacities for local communities to address the impacts of SLR; 5) strengthening sanitation and environmental control within the area of the protected area; and, 6) guaranteeing regional food security.

The case of Invasive Alien Species in the Rio de la Plata estuary (Argentina-Uruguay)

The most invasive alien species in the Rio de la Plata estuary (RdIP) and river basin were euryhaline species (tolerant to salinity gradients), accidentally introduced by ballast water (Brugnoli et al., 2005; Muniz et al., 2005). The freshwater mollusc golden mussel (Limnoperna fortunei), native to Southeast China was found associated with natural and artificial hard substrates, increasing its population abundances, and causing changes in the benthic communities (Boltovskoy and Correa, 2015). Rapana venosa is a predator of subtidal molluscs, usually feeding on bivalves such as oysters, mussels and clams (Giberto et al., 2011; Lanfranconi et al., 2013) found in the muddy bottoms of the subtidal mixohaline zone of the RdIP (Giberto and Bruno, 2014).

The environmental research of alien species in the RdIP has focused on changes in river flows and the mapping of salinity thresholds that favoured the colonisation of Limnoperna fortunei in the inner estuary and Rapana venosa in the sediments of the intermediate zone. Currently, the management strategy focuses on fishing IAS with non-destructive fishing gear (e.g. pots) (Brugnoli et al., 2014).

National Adaptation Programmes of Action (NAPAs)

Climate policies in Central and South America focus mostly on adaptation to the impacts of climate change and variability. A few countries (Brazil, Colombia, and Chile) have submitted their NAPAs under the Paris Agreement (http://www4.unfccc.int/nap/Pages/nationaladaptation-plans.aspx), and only Brazil developed in 2016 actions to promote climate change adaptation in the coastal zone References??. The Brazilian government is currently? developing a set of studies, methodologies, and tools, in collaboration with different scientific institutions, for the comprehension and diagnosis of exposure and vulnerability to climate change aimed at modelling risks and generating responses. References??.

In Uruguay, the National Climate Change Policy was newly developed to promote climate change adaptation with stakeholder's involvemens. In this regard, the country has drawn up 
the Nationally Determined Contribution per sector and implemented a set of objectives to elaborate sector-specific NAPAs simultaneously. Low-lying flood-prone areas in Uruguay are vulnerable to the combination of increasing storm surges with SLR (Calil et al., 2017; Losada et al., 2013). Therefore, the coastal NAPA developed adaptation measures and plans focused on building local capacity to monitor SLR and storms. The main adaptation actions undertaken through the coastal-specific NAPA are the following:

1) Strengthening of the National Protected Areas Systems.

2) Promotion of EBA and restoration and maintenance of coastal ecosystem services that protect against climate-related hazards.

3) Articulate and develop new integrated climate services and information systems, for continuous monitoring, risk mapping, and loss and damage evaluation.

4) Build research and development capacities to enhance domestic response to climate change and variability.

Summary

Climate change is projected to be a significant driver of further degradation of most coastal ecosystems, biodiversity and ecosystem services in Latin America (IPBES, 2018).

Most updated socioeconomic and vulnerability indices, shown in Table 2, agree with the conclusions of several studies presented in this article (e.g. Calil et al., 2017; Nagy et al., 2018; Villamizar et al., 2017) about the vulnerability in Central and South America. Belize, Guatemala, Honduras, El Salvador, Nicaragua, and Guyana, are the most vulnerable countries, whereas Argentina, Chile, Uruguay, and Brazil are comparatively less vulnerable.

Low-income levels and a lack of resources, lack of data (mainly the absence of long-term sealevel records in most countries), lack of capacity, non-adequate regulatory frameworks, early warning systems, and limited political interest, usually hinder current coastal management approaches to climate-related hazards. The current adaptation deficit to climate change and variability in Central and South America is likely to remain so, unless fundamental changes in both decision-making processes and policies are implemented.

Mainstreaming climate change adaptation in CSA's coastal areas is somewhat new: most countries introduced their national strategies during the last decade. Strategies such as community-based (CBA), ecosystem-based (EBA), Public Policy System Model (PPSM), and National Adaptation Programmes of Action (NAPAs) should be strengthened in the region.

Some perspectives of future research and management $=$ this sub-section is too short, perhaps merge with the previous one?

Future research and adaptation should systematically evaluate risks under alternative scenarios of future climatic and societal CSA conditions, and monitor indicators associated with the IPCC Reasons for Concern framework, to detect the transition from weak to moderate and high impacts. 
The current adaptation deficit in CSA countries is an opportunity to foster adaptive capacity by mainstreaming adaptation plans to face climate-related hazards into national strategies.

\section{References}

ACFIMAN-SACC, 2018. Primer Reporte Académico de Cambio Climático. Resumen para Responsables de Políticas en Cambio Climático para Venezuela: Contribución de los Grupos de Trabajo I, II y III al Primer Reporte Académico de Cambio Climático (PRACC) de la Secretaría Académica de Cambio Climático (SACC) de la Academia de Ciencias Físicas, Matemáticas y Naturales (ACFIMAN) de Venezuela. [A. Villamizar, E. Buroz Castillo, R. Lairet Centeno and J. Gómez (Eds.)]. Ediciones ACFIMAN - CITECl, Caracas, Venezuela.

Adame, M.F., Brown, C.J., Bejarano, M., Herrera-Silveira, J.A., Ezcurra, P., Kauffman, J.B., Birdsey, R.A., 2018. The undervalued contribution of mangrove protection in Mexico to carbon emission targets. Conserv. Lett. e12445. http://sci-hub.tw/10.1111/conl.12445

Betancur-R., R., Hines, A., Acero, A.P., Ortí, G., Wilbur, A.E., Freshwater, D.W., 2011.

Reconstructing the lionfish invasion: insights into Greater Caribbean biogeography. J. Biogeogr. 38, 1281-1293. http://sci-hub.tw/10.1111/j.1365-2699.2011.02496.x

Blackburn, T.M., Essl, F., Evans, T., Hulme, P.E., Jeschke, J.M., Kühn, I., Kumschick, S., Marková, Z., Mrugała, A., Nentwig, W., Pergl, J., Pyšek, P., Rabitsch, W., Ricciardi, A., Richardson, D.M., Sendek, A., Vilà, M., Wilson, J.R.U., Winter, M., Genovesi, P., Bacher, S., 2014. A unified classification of alien species based on the magnitude of their environmental impacts. PLoS Biol. 12, e1001850. http://sci-hub.tw/10.1371/journal.pbio.1001850

Boltovskoy, D., Correa, N., 2015. Ecosystem impacts of the invasive bivalve Limnoperna fortunei (golden mussel) in South America. Hydrobiologia 746, 81-95. http://scihub.tw/10.1007/s10750-014-1882-9

Braga, H. de O., Azeiteiro, U.M., Oliveira, H.M.F., Pardal, M.A., 2018. Conserving Brazilian Sardine: Fisher's attitudes and knowledge in the Marine Extractive Reserve of Arraial do Cabo, Rio de Janeiro State, Brazil. Fish. Res. 204, 402-411. http://scihub.tw/10.1016/j.fishres.2018.03.019

Breithaupt, J.L., Smoak, J.M., Smith III, T.J., Sanders, C.J., Hoare, A., 2012. Organic carbon burial rates in mangrove sediments: Strengthening the global budget. Global Biogeochem. Cycles 26, GB3011. http://sci-hub.tw/10.1029/2012gb004375

Brugnoli, E., Clemente, J., Boccardi, L., Borthagaray, A.I., Scarabino, F., 2005. Golden mussel Limnoperna fortunei (Bivalvia: Mytilidae) distribution in the main hydrographical basins of Uruguay: update and predictions. An. Acad. Bras. Cienc. 77, 235-244. http://scihub.tw/10.1590/S0001-37652005000200004

Brugnoli, E., Giberto, D.A., Lanfranconi, A., Schiariti, A., Aguilera, F., Bremec, C.S., Barrero, G., Muniz, P., 2014. El gasterópodo invasor Rapana venosa (Valenciennes 1846) y sus posibles efectos en el ecosistema costero estuarial del Río de la Plata, in: Goso Aguilar, C. (Ed.), Nuevas 
Miradas a La Problemática de Los Ambientes Costeros: Sur de Brasil, Uruguay y Argentina. DIRAC, Facultad de Ciencias, Universidad de la República, Montevideo, Uruguay, pp. 211-228.

Brugnoli, E., Verocai, J.E., Muniz, P., García-Rodríguez, F., 2018. Weather, hydrological and oceanographic conditions of the northern coast of the Rio de la Plata estuary during ENSO 2009-2010, in: Froneman, W. (Ed.), Estuary. InTech, London, United Kingdom, pp. 19-38. http://sci-hub.tw/10.5772/intechopen.71808

Cai, W., Borlace, S., Lengaigne, M., van Rensch, P., Collins, M., Vecchi, G., Timmermann, A., Santoso, A., McPhaden, M.J., Wu, L., England, M.H., Wang, G., Guilyardi, E., Jin, F.-F., 2014. Increasing frequency of extreme El Niño events due to greenhouse warming. Nat. Clim. Chang.4, 111-116. http://sci-hub.tw/10.1038/nclimate2100

Calil, J., Reguero, B.G., Zamora, A.R., Losada, I.J., Méndez, F.J., 2017. Comparative Coastal Risk Index (CCRI): A multidisciplinary risk index for Latin America and the Caribbean. PLoS One 12, e0187011. http://sci-hub.tw/10.1371/journal.pone.0187011

Carro, I., Seijo, L., Nagy, G.J., Lagos, X., Gutiérrez, O., 2018. Building capacity on ecosystembased adaptation strategy to cope with extreme events and sea-level rise on the Uruguayan coast. Int. J. Clim. Chang. Strateg. Manag. 10, 504-522. http://sci-hub.tw/10.1108/IJCCSM-072017-0149

CBD, 2018. Glossary of terms [WWW Document]. Invasive Alien Species. URL https://www.cbd.int/invasive/terms.shtml

CBD, 2016. Quick guide to the Aichi Biodiversity Targets, pressures on vulnerable ecosystems reduced [WWW Document]. Convention of Biological Diversity. URL https://www.cbd.int/doc/strategic-plan/targets/T10-quick-guide-en.pdf (accessed 11.16.16).

CCCCC, 2017. 2014-2018 Coastal Protection for Climate Change Adaptation in the Small Island States in the Caribbean (KfW) [WWW Document]. Caribbean Community Climate Change Centre. URL http://www.caribbeanclimate.bz/2014-2018-coastal-protection-for-climatechange-adaptation-in-the-small-island-states-in-the-caribbean-kfw/ (accessed 7.27.18).

Devaney, J.L., Lehmann, M., Feller, I.C., Parker, J.D., 2017. Mangrove microclimates alter seedling dynamics at the range edge. Ecology 98, 2513-2520. http://scihub.tw/10.1002/ecy.1979

ECLAC, 2018. The Caribbean Outlook, 2018. Economic Commission for Latin America and the Caribbean, (LC/SES.37/14/Rev.1), Santiago.

EuropeAid, 2009. Climate change in Latin America. Consortium AFCO, Agrifor Consult, European Commission, Les Isnes, Belgium.

Ferreira, C.E.L., Luiz, O.J., Floeter, S.R., Lucena, M.B., Barbosa, M.C., Rocha, C.R., Rocha, L.A., 2015. First record of invasive lionfish (Pterois volitans) for the Brazilian coast. PLoS Onr 10, e0123002. http://sci-hub.tw/10.1371/journal.pone.0123002 
Garnett, P., 2018. Total systemic failure? Sci. Total Environ. 626, 684-688. http://scihub.tw/10.1016/J.SCITOTENV.2018.01.075

Giberto, D.A., Bruno, L.I., 2014. Recent records of the exotic gastropod Rapana venosa (Valenciennes, 1846) along the Argentine coastline: is the invasion progressing southwards? Panam. J. Aquat. 9, 324-330.

Giberto, D.A., Schiariti, A., Bremec, C.S., 2011. Diet and daily consumption rates of Rapana venosa (Valenciennes, 1846) (Gastropoda: Muricidae) from the Río de la Plata (ArgentinaUruguay). J. Shellfish Res. 30, 349-358. http://sci-hub.tw/10.2983/035.030.0222

Godoy, M.D.P., Lacerda, L.D. de, 2015. Mangroves response to Climate Change: A review of recent findings on mangrove extension and distribution. An. Acad. Bras. Cienc. 87, 651-667. http://sci-hub.tw/10.1590/0001-3765201520150055

Guarderas, A.P., Hacker, S.D., Lubchenco, J., 2008. Current status of marine protected areas in Latin America and the Caribbean. Conserv. Biol. 22, 1630-1640. http://sci-

hub.tw/10.1111/j.1523-1739.2008.01023.x

Gutiérrez, O., Panario, D., Nagy, G.J., Bidegain, M., Montes, C., 2016. Climate teleconnections and indicators of coastal systems response. Ocean Coast. Manag. 122, 64-76. http://scihub.tw/10.1016/j.ocecoaman.2016.01.009

Hellmann, J.J., Byers, J.E., Bierwagen, B.G., Dukes, J.S., 2008. Five potential consequences of Climate Change for invasive species. Conserv. Biol. 22, 534-543. http://scihub.tw/10.1111/j.1523-1739.2008.00951.x

IPBES, 2018. Summary for policymakers of the regional assessment report on biodiversity and ecosystem services for the Americas of the Intergovernmental Science-Policy Platform on Biodiversity and Ecosystem Services. Intergovernmental Science-Policy Platform on Biodiversity and Ecosystem Services - IPBES Secretariat, Bonn, Germany.

IPCC, 2014a. Annex II: Glossary [Mach, K.J., S. Planton and C. von Stechow (eds.)], in: Climate Change 2014: Synthesis Report. Contribution of Working Groups I, II and III to the Fifth Assessment Report of the Intergovernmental Panel on Climate Change [Core Writing Team, R.K. Pachauri and L.A. Meyer (Eds.)]. IPCC, Geneva, Switzerland, pp. 117-130.

IPCC, 2014b. Climate Change 2014: Impacts, Adaptation and Vulnerability. Part B: Regional Aspects. Contribution of Working Group II to the Fifth Assessment Report of the Intergovernmental Panel on Climate Change. Cambridge University Press, Cambridge, United Kingdom and New York, NY, USA.

IPCC, 2014c. Summary for Policymakers, in: Climate Change 2014: Mitigation of Climate Change. Contribution of Working Group III to the Fifth Assessment Report of the Intergovernmental Panel on Climate Change. Cambridge University Press, Cambridge, United Kingdom.

IPCC, 2014d. Climate Change 2014: Impacts, Adaptation, and Vulnerability. Part A: Global and Sectoral Aspects. Contribution of Working Group II to the Fifth Assessment Report of the 
Intergovernmental Panel on Climate Change. Cambridge University Press, Cambridge, United Kingdom. http://sci-hub.tw/10.1017/CBO9781107415379

IPCC, 2012. Managing the risks of extreme events and disasters to advance climate change adaptation. A special report of Working Groups I and II of the Intergovernmental Panel on Climate Change. Cambridge University Press, Cambridge, United Kingdom.

IPCC, 2007. Climate Change 2007: Synthesis Report. Contribution of Working Groups I, II and III to the Fourth Assessment Report of the Intergovernmental Panel on Climate Change. IPCC, Geneva, Switzerland.

Izaguirre, C., Méndez, F.J., Espejo, A., Losada, I.J., Reguero, B.G., 2013. Extreme wave climate changes in Central-South America. Clim. Chang. 119, 277-290. http://sci-

hub.tw/10.1007/s10584-013-0712-9

Lanfranconi, A., Brugnoli, E., Muniz, P., 2013. Preliminary estimates of consumption rates of Rapana venosa (Gastropoda, Muricidae); a new threat to mollusk biodiversity in the Río de la Plata. Aquat. Invasions 8, 437-442. http://sci-hub.tw/10.3391/ai.2013.8.4.07

Leal Filho, W., Mannke, F., 2014. Managing the impacts of climate change in Latin America: the need for technology transfer, in: Leal Filho, W., Alves, F., Caeiro, S., Azeiteiro, U.M. (Eds.), International Perspectives on Climate Change: Latin America and Beyond, Climate Change Management. Springer International Publishing, Cham, Switzerland, pp. 95-106. http://scihub.tw/10.1007/978-3-319-04489-7_7

Leal Filho, W., Modesto, F., Nagy, G.J., Saroar, M.M., YannickToamukum, N., Ha'apio, M., 2018. Fostering coastal resilience to climate change vulnerability in Bangladesh, Brazil, Cameroon, and Uruguay: a cross-country comparison. Mitig. Adapt. Strateg. Glob. Chang. 23, 579-602. http://sci-hub.tw/10.1007/s11027-017-9750-3

Losada, I.J., Reguero, B.G., Méndez, F.J., Castanedo, S., Abascal, A.J., Mínguez, R., 2013. Longterm changes in sea-level components in Latin America and the Caribbean. Glob. Planet. Change 104, 34-50. http://sci-hub.tw/10.1016/j.gloplacha.2013.02.006

Magrin, G.O., Gay García, C., Cruz Choque, D., Giménez, J.C., Moreno, A.R., Nagy, G.J., Nobre, C.A., Villamizar, A., 2007. Latin America, in: Parry, M.L., Canziani, O.F., Palutikof, J.P., Linden, P.J. van der, Hanson, C.E. (Eds.), Climate Change 2007: Impacts, Adaptation and Vulnerability. Contribution of Working Group II to the Fourth Assessment Report of the Intergovernmental Panel on Climate Change. Cambridge University Press, Cambridge, United Kingdom, pp. 581615.

Magrin, G.O., Marengo, J.A., Boulanger, J.-P., Buckeridge, M.S., Castellanos, E., Poveda, G., Scarano, F.R., Vicuña, S., 2014. Central and South America, in: Barros, V., Field, C.B., Dokken, D.J., Mastrandrea, M.D., Mach, K.J., Bilir, T.E., Chatterjee, M., Ebi, K.L., Estrada, Y.O., Genova, R.C., Girma, B., Kissel, E.S., Levy, A.N., MacCracken, S., Mastrandrea, P.R., White, L.L. (Eds.), Climate Change 2014: Impacts, Adaptation and Vulnerability. Part B: Regional Aspects. Contribution of Working Group II to the Fifth Assessment Report of the Intergovernmental 
Panel on Climate Change. Cambridge University Press, Cambridge, United Kingdom, pp. 14991566.

Muniz, P., Clemente, J., Brugnoli, E., 2005. Benthic invasive pests in Uruguay: a new problem or an old one recently perceived? Mar. Pollut. Bull. 50, 1014-1018. http://scihub.tw/10.1016/j.marpolbul.2005.06.049

Muñoz Sevilla, N.P., Le Bail, M., 2017. Latin American and Caribbean regional perspective on Ecosystem-based Management (EBM) of large marine ecosystems goods and services. Environ. Dev. 22, 9-17. http://sci-hub.tw/10.1016/j.envdev.2017.01.006

Nagy, G.J., Gómez-Erache, M., Fernández, V., 2007. El aumento del nivel del mar en la costa uruguaya del Río de la Plata. Tendencias, vulnerabilidades y medidas para la adaptación. Medio Ambient. y Urban. 67, 77-93.

Nagy, G.J., Gómez-Erache, M., Kay, R., 2015. A risk-based and participatory approach to assessing climate vulnerability and improving governance in coastal Uruguay, in: Glavovic, B., Kelly, M., Kay, R., Travers, A. (Eds.), Climate Change and the Coast Building Resilient Communities. CRC Press, Boca Raton, Florida, U.S.A., pp. 357-378. http://scihub.tw/10.1201/b18053-23

Nagy, G.J., Gutiérrez, O., 2018. Scenario planning toward climate adaptation: The Uruguayan coast, in: Leal Filho, W., Esteves de Freitas, L. (Eds.), Climate Change Adaptation in Latin America. Managing Vulnerability, Fostering Resilience, Climate Change Management Series. Springer, Cham, Switzerland, pp. 457-476. http://sci-hub.tw/10.1007/978-3-319-56946-8_28

Nagy, G.J., Leal Filho, W., Azeiteiro, U.M., Heimfarth, J., Verocai, J.E., Li, C., 2018. An assessment of the relationships between extreme weather events, vulnerability, and the impacts on human wellbeing in Latin America. Int. J. Environ. Res. Public Health 15, 1802. http://sci-hub.tw/10.3390/ijerph15091802

Nagy, G.J., Muñoz, N., Verocai, J.E., Bidegain, M., Seijo, L., 2014a. Adjusting to current climate threats and building alternative future scenarios for the Rio de la Plata coast and estuarine front, Uruguay. J. Integr. Coast. Zo. Manag. - Rev. Gestão Costeira Integr. 14, 553-568. http://sci-hub.tw/10.5894/rgci472

Nagy, G.J., Seijo, L., Verocai, J.E., Bidegain, M., 2014b. Stakeholders' climate perception and adaptation in coastal Uruguay. Int. J. Clim. Chang. Strateg. Manag. 6, 63-84. http://scihub.tw/10.1108/IJCCSM-03-2013-0035

ND-Gain, 2016. ND-GAIN Country Index. University of Notre Dame [WWW Document]. URL http://index.gain.org/

Neumann, B., Vafeidis, A.T., Zimmermann, J., Nicholls, R.J., 2015. Future coastal population growth and exposure to sea-level rise and coastal flooding - A global assessment. PLoS One 10, e0118571. http://sci-hub.tw/10.1371/journal.pone.0118571 
NOAA, 2018. Sea Level Trends [WWW Document], in: Tides and currents. National Oceanic and Atmospheric Administration. URL https://tidesandcurrents.noaa.gov/sltrends/ (accessed 7.6.18).

O'Neill, B.C., Oppenheimer, M., Warren, R., Hallegatte, S., Kopp, R.E., Pörtner, H.O., Scholes, R., Birkmann, J., Foden, W., Licker, R., Mach, K.J., Marbaix, P., Mastrandrea, M.D., Price, J., Takahashi, K., van Ypersele, J.-P., Yohe, G., 2017. IPCC reasons for concern regarding climate change risks. Nat. Clim. Chang. 7, 28-37. http://sci-hub.tw/10.1038/nclimate3179

OHI, 2017. 2017 Global Scores for Ocean Health [WWW Document], in: Ocean Health Index. URL http://www.oceanhealthindex.org/news/2017-ocean-health-index-global-scores

PSMSL, 2017. Table of relative Mean Sea Level secular trends derived from Permanent Service for Mean Sea Level (PSMSL) RLR Data (Last updated 15-Jan-2017) [WWW Document]. National Oceanic and Atmospheric Administration (NOAA). URL http://www.psmsl.org/products/trends/trends.txt (accessed 29.3.19).

Raicich, F., 2008. A review of sea level observations and low frequency sea-level variability in South Atlantic. Phys. Chem. Earth, Parts A/B/C 33, 239-249. http://scihub.tw/10.1016/J.PCE.2007.04.001

Scherer, M., Costa, M.F., Boski, T., Azeiteiro, U.M., Dias, J.M.A., 2014. Integrated coastal management in Latin America: the ever new world. J. Integr. Coast. Zo. Manag. - Rev. Gestão Costeira Integr. 14, 663-668. http://sci-hub.tw/10.5894/rgci575

Schofield, P.J., 2009. Geographic extent and chronology of the invasion of non-native lionfish (Pterois volitans [Linnaeus 1758] and P. miles [Bennett 1828]) in the Western North Atlantic and Caribbean Sea. Aquat. Invasions 4, 473-479. http://sci-hub.tw/10.3391/ai.2009.4.3.5

Silva, R., Martínez, M.L., Hesp, P.A., Catalan, P., Osorio, A.F., Martell, R., Fossati, M., Miot da Silva, G., Mariño-Tapia, I., Pereira, P., Cienguegos, R., Klein, A., Govaere, G., 2014. Present and future challenges of coastal erosion in Latin America. J. Coast. Res. 71, 1-16. http://scihub.tw/10.2112/SI71-001.1

Spalding, M., Kainuma, M., Collins, L., 2011. World Atlas of Mangroves. Earthscan, London, United Kingdom.

U.S. Climate Resilience Toolkit, 2018. Glossary [WWW Document]. URL https://toolkit.climate.gov/content/glossary (accessed 7.6.18).

Ummenhofer, C.C., Meehl, G.A., 2017. Extreme weather and climate events with ecological relevance: a review. Philos. Trans. R. Soc. B Biol. Sci. 372, 20160135. http://scihub.tw/10.1098/rstb.2016.0135

UN-HABITAB, 2008. Latin america and Caribbean cities at risk due to sea-level [WWW Document]. Global Urban Observatory. URL https://www.preventionweb.net/files/5649_latinamericascaribbean.pdf (accessed 5.5.18). 
UNDP, 2016. Human Development Report 2016: Human Development for Everyone. United Nations Development Programme, New York, U.S.A.

UNEP-ECLAC, 2010. Vital Climate Change Graphics for Latin America and the Caribbean. Special edition for the COP 16/CMP 6, Mexico. DEW/1325/PA, UNEP, ECLAC, UNEP/GRID-Arendal, Santiago, Chile.

United Nations, 2015. Transforming our world: The 2030 agenda for sustainable development. A/RES/70/1. Resolution adopted by the General Assembly.

Verocai, J.E., Gómez-Erache, M., Nagy, G.J., Bidegain, M., 2015. Addressing climate extremes in Coastal Management: The case of the Uruguayan coast of the Rio de la Plata System. J. Integr. Coast. Zo. Manag. - Rev. Gestão Costeira Integr. 15, 91-107. http://sci-hub.tw/10.5894/rgci555

Verocai, J.E., Nagy, G.J., Bidegain, M., 2016. Sea-level trends along freshwater and seawater mixing in the Uruguayan Rio de la Plata estuary and Atlantic Ocean coast. Int. J. Mar. Sci. 6, 118. http://sci-hub.tw/10.5376/ijms.2016.06.0007

Vieira, B.P., 2016. Population trends and conservation of the Mangrove Rail. Rev. Bras. Ornitol. 23, 327-335.

Vilà, M., Ibáñez, I., 2011. Plant invasions in the landscape. Landsc. Ecol. 26, 461-472. http://scihub.tw/10.1007/s10980-011-9585-3

Villamizar, A., 2011. Políticas de adaptación ante los impactos del aumento en el nivel del mar Caso de Estudio: Costas bajas de la Reserva de Fauna Silvestre Hueque-Sauca. Edo. Falcón .Seminar postgraduated on Sustainable Development. Unidad de Políticas Públicas. Universidad Simón Bolívar.

Villamizar, A., Gutiérrez, M.E., Nagy, G.J., Caffera, R.M., Leal Filho, W., 2017. Climate adaptation in South America with emphasis in coastal areas: the state-of-the-art and case studies from Venezuela and Uruguay. Clim. Dev. 9, 364-382. http://scihub.tw/10.1080/17565529.2016.1146120

Walther, G.-R., Roques, A., Hulme, P.E., Sykes, M.T., Pyšek, P., Kühn, I., Zobel, M., Bacher, S., Botta-Dukát, Z., Bugmann, H., Czúcz, B., Dauber, J., Hickler, T., Jarošík, V., Kenis, M., Klotz, S., Minchin, D., Moora, M., Nentwig, W., Ott, J., Panov, V.E., Reineking, B., Robinet, C., Semenchenko, V., Solarz, W., Thuiller, W., Vilà, M., Vohland, K., Settele, J., 2009. Alien species in a warmer world: risks and opportunities. Trends Ecol. Evol. 24, 686-693. http://scihub.tw/10.1016/J.TREE.2009.06.008

WMO, 2019. Statement on the State of the Global Climate in 2018. World Meteorological Organization, No 1233, Geneva, Switzerland.

Wong, P.P., Losada, I.J., Gattuso, J.-P., Hinkel, J., Khattabi, A., McInnes, K.L., Saito, Y., Sallenger, A., 2014. Coastal systems and low-lying areas, in: Field, C.B., Barros, V., Dokken, D.J., Mach, K.J., Mastrandrea, M.D., Bilir, T.E., Chatterjee, M., Ebi, K.L., Estrada, Y.O., Genova, R.C., Girma, B., Kissel, E.S., Levy, A.N., MacCracken, S., Mastrandrea, P.R., White, L.L. (Eds.), Climate Change 2014: Impacts, Adaptation and Vulnerability. Part A: Global and Sectoral Aspects. Working 
Group II. Contribution to the Fifth Assessment Report of the Intergovernmental Panel on Climate Change. Cambridge University Press, Cambridge, United Kingdom, pp. 361-409.

Yáñez-Arancibia, A., Lara-Domínguez, A.L. (Eds.), 1999. Ecosistemas de Manglar en América Tropical. Instituto de Ecología, A.C. Xalapa, México; UICN/ORMA Costa Rica; NOAA/NMFS, Silver Spring MO, U.S.A. 